\title{
Development and Strategy Research Based on E-Commerce Network Financial Accounting
}

\author{
Xiumei ZHU \\ Weifang University of Science and Technology \\ Shouguang,Weifang,Shandong, 262700 China
}

\begin{abstract}
Network Accounting and Traditional Affairs comparative accounting has many advantages, but because of the limitations of the characteristics of the network and open itself defective resources, and the times of network accounting software, accounting professionals and advanced network slow down the development of network accounting. In this paper, the development of the times in the presence of network accounting is to take advantage of proposed countermeasures.
\end{abstract}

Keywords- E-commerce; the Network of Financial Accounting; Problem; Countermeasure

\section{INTRODUCTION}

\section{A. Network Accounting Concepts}

Academic "network accounting 'understanding of the concept is still relatively uniform, that" network accounting refers to the Internet environment on a variety of transactions and matters recognition, measurement and disclosure of accounting activities. ". Its connotation includes the following four points: network Accounting is based on the premise of accounting information system under the Internet environment; by the information technology and accounting knowledge together. It is to put a lot of financial information companies that need to handle stored in electronic form; there are various accounting matters to the recognition, measurement and disclosure. It is an important part of ecommerce component. Based on the above meaning, some scholars' network accounting and value chain are accounting for comparison, the required characteristics of financial information, information systems, and object information service of view, that the value chain accounting and network accounting consolidation characteristics of financial accounting and management accounting.

\section{B. Network Accounting Target}

Seen by the connotation of network accounting, network accounting information system is by means of the platform, but it is to serve the corporate accounting activities, so it must be the goal of integrating the target information systems for corporate accounting. The role of information systems that improve the overall management level and the purpose of business are to provide decision-making basis of accounting, the ultimate goal of both services be for corporate profits. So the target network accounting should improve the management level through to provide basis for decision-making, efficient allocation of resources, enhance corporate profitability. Some scholars from the financial information of view, that with the advent of the Internet age, network accounting function will also shift information supply, information assurance and information consumption [. Understand their views can be summed up as follows: the future users of financial information includes not only the existing stakeholders, but also includes the potential stakeholders; the cost of obtaining financial information has been a significant decline, but it is also to facilitate financial analysis of late; Finance voluntary disclosure of information would impede mining analysis of information.

\section{Analysis of the feasibility and necessity of network accounting}

Enterprises accounting network has its inherent feasibility and necessity. From feasibility point of view, the technical level of WEB technology has large database technology and three structural components and firewall (Firewall). The successful application of technology for the network is to provide a solid accounting technical support. In productivity, as computer acquisition cost and a lot of development costs of a significant decline in network usage, and a variety of information systems, it is allowing companies to implement a network of accounting as possible. The network accounting application level, the network into people's lives can create a favorable environment for ecommerce in addition to conditions, but is also makes financial staff to work from home to become a reality, making timely accounting information processing greatly enhanced. From the viewpoint of necessity, through the implementation of enterprise network, it can avoid the limitations of the existing accounting computerized accounting, accounting information distortion occurs, operations management loopholes and other issues, but it is also to create favorable conditions for the development of ecommerce, so companies implement network accounting work that is necessary. 


\section{ISSUES OF DEVELOPMENT OF E-COMMERCE ACCOUNTING}

\section{A. The international development issues of Accounting}

E-commerce can narrow the distance between the world and the world economy into one. In a very short period of time, it is to enhance the degree of capital circulation and it has efforts to achieve a huge amount of money in turnover over the world to accelerate capital investment and liquidity in the international arena. Business standing in the international arena, it is to seek survival and development in the international competition the storm, which only needs to have a strong foothold in the capital, but also need to invest huge amounts of money to eliminate backward production capacity and technology. It can continue to strengthen the development of new products and technology developed. Where are these huge amounts of money? Only a few companies can rely on accumulation or by their financial institution loans to support their own income, and most companies need to raise funds to international development, which makes a kind of international law that will inevitably lead to borrowing money. It also requires a country to be lent money to develop better credit decisions, it must also credit status and financial situation of foreign borrowing units do the investigation. E-commerce is into international trade, it is necessary to understand the financial statements and the accounting system of foreign companies require standardized financial statements in line with international practice and establish a uniform accounting procedures and methods. Those are based on the development of international accounting issues worthy of our consideration.

\section{B. Virtualization issues in the accounting entity}

Accounting entity refers to the object targeted by the accounting services. Accounting entity [5] describes a traditional unit of real entities. In the e-commerce process, it is prompting the body to break the traditional accounting space that extends to the world, changing the spatial characteristics of the entity body. Networked makes strategic alliances multinational company linked more closely to make long-distance, multi-object business services centralized financial accounting management possible. Network information flow, business flow, reducing many intermediate links, the optimal operation of the channel to meet customer needs to the maximum extent and the fastest, lowest cost to enter the international market network. Starting online banking to make liquidity, electronic settlement documents, and logistics placement becomes convenient, showing the object of international trade, electronic transaction procedures, and the transaction process intangible. Thus, the formation of a network of e-commerce environment enables virtual accounting entity that came into being. This network accounting entity by means of a computer is completely invisible, paperless operation. But, there is no doubt, with some venues, there is no clear office, or even the invisible virtualized networking companies, Internet companies. Virtualization accounting entity depends on the information users need, with the market changes rapidly and quickly shifting alliances, or even disappear. In the age of electronic commerce, network virtualization accounting entity is in a fuzzy state, these virtual online business and Internet business are for new economic to form a network of economic subjects, how to identify its virtual nature, it is worth considering.

\section{Accounting professional and technical personnel issues}

In the e-commerce activities, e-commerce accounting, and accounting network are combining high-tech products, its accounting staff, high quality requirements of the appropriate management personnel, both are requiring them to be proficient in computer network knowledge, basic troubleshooting capabilities Basic computer skills and maintenance require them to have a deep theoretical knowledge and skilled accounting skills. As the network environment makes accounting simple, the entire financial services companies are to become one of the central links in the chain, accounting management personnel that must have relevant knowledge and network knowledge. At the same time, because of the accounting staff to provide accurate cost information accounting information, we must understand the specific production process and product technology, basic knowledge relevant industries. Accounting is also facing human resource accounting structure, information, knowledge, and other new issues denominated in other intangible assets, which also requires the accounting officer not only to have extensive knowledge, but also to have the ability to innovate knowledge to meet the needs of the development of the network economy accounting. Currently, some enterprises accountants have low level of technical expertise, practical ability is not strong, and they cannot meet the requirements for the development of e-commerce accounting, education and training need to be improved.

\section{E-commerce network security issues of Accounting}

With the rapid development of network technology, ecommerce is in order to operate in the form of data, electronic documents, use, accounting network to bring a lot of new problems. Because of the openness of the Internet features, the accounting information secures vulnerable to threats. Electronic symbols instead of accounting data, accounting information through the network transmission, transfer of intangible assets, are to make safety hazard identification, internal control, internal audit of increasing difficulty, the original documents digitized is easy to forge the lack of effective accounting restraint, leaving no trace of memory data, system files are unreadable. Data input by the designated processing program is bringing the potential problem of electronic data processing. Functional aspects of the division of the boundaries blur restrictive relationship between the general ledger and subsidiary ledgers that disappear. If the system is running the program with a little mistake, it will lead to a chain of errors and repeatability. Obtain authorization are illegal, such as passwords, unauthorized management and operational issues worth considering. 


\section{THREE KEY ISSUES CONSTRAINING THE DEVELOPMENT OF E-COMMERCE NETWORK ACCOUNTING}

\section{A. Accounting entity virtualization issues}

Accounting entity refers to the object targeted by the accounting services. Traditional accounting entity describes a real physical units, accounting body in the virtual age of electronic commerce have emerged. Network accounting entity is entirely by means of computer invisible, paperless operation, that is, network virtualization accounting entity is in a fuzzy state, this virtual online is for business, Internet business is to new economic form a network of economic agents. Virtualization accounting information users need to combine the main visual changes in the market, based on the rapid development of e-commerce faster financial accounting of enterprises. Its illegible virtual nature is worth considering.

\section{B. Accounting international development issues}

Internet and multinational companies have contributed to the emergence and development of e-commerce. Features contemporary commerce transactions is funding the rapid flow of international and complicated process; therefore cross-border e-commerce transactions business when it is necessary to understand the financial statements and the accounting system of foreign companies, in order to prevent the parties to the transaction details which led to the transaction fails. So in order to adapt to the global economy of e-commerce network development requirements of the relevant organizations, it is to provide financial statements in accordance with international standardization of practices, and establish a uniform accounting procedures and methods.

\section{E-commerce security issues accounting}

With the rapid development of Internet technology, ecommerce accounting personnel data processing, electronic documents have become familiar with the operation of ecommerce that still exposed many security issues. Enterprises in the use of the Internet and its trading partners are in the online transaction that is completed, which will expose their own risk; it is including network hacker attacks deliberately making enterprise management system failures. When unauthorized, persons have information showing the use of transaction trespasses enterprise information systems to steal trade secrets and other. Network security risks are due to the immaturity of network technology and electronic technology caused. Although e-commerce intelligent is not a hundred percent on erroneous data to identify, illegal workers through illegal techniques digitized original documents forgery, deception corporate resources. Enterprise systems run the program with error; it will lead to a chain of data errors and repeatability.

\section{E-commerce accounting professional and technical personnel issues}

Currently, some companies cannot be professional accountants accounting requirements of development of ecommerce, data processing ability to operate e-commerce network is not strong accounting, education and training need to be improved. E-commerce is a high-tech product accounting, network accounting personnel requirements are complex talent, which must have two computers and accounting professional knowledge and skills. It is including networking knowledge, troubleshooting skills, computer skills, and basic maintenance of the accounting profession theoretical knowledge and skill accounting business skills; it is a positive innovation to continuously improve the level of accounting.

\section{MeAsures to Promote THE DEVElopment of E- COMMERCE NETWORK OF FINANCIAL ACCOUNTING}

\section{A. Strengthen the construction of e-commerce accounting network}

Currently, most companies are confined to the local area network to conduct business, which has been a serious impediment to commerce, accounting network playback performance. For this reason, the disclosure should be for different audiences, network construction rich in content can accelerate WAN direction. It is to continue to increase the transmission range of information, open financial information transmission channels. In accordance with the network accounting functions, the establishment of a network platform is the Internet, intranet, extranet, and other communications networks. With the development of network technology, e-commerce network of accounting standards, not only can provide accounting information, but also to provide all possible accounting methods.

\section{B. Create an integrated e-commerce operation network system}

Financial and accounting management of the implementation of e-commerce network core, we must be based on a multi-user operation, the use of modern management techniques, accounting content, accounting methods and accounting methods, create from a person's overall business networks. Implementation of electronic network has accounting, management and decision-making, improve capital, cost and quality management systems, databases, languages, systematic data sharing, data entry.

\section{Train e-commerce network of accounting professionals}

E-commerce professional core competence lies in technical talent competition, it should also include modeling capabilities, network marketing capabilities, the ability to ecommerce business website building process. It is to understand the business model and so on. Demos online banking transactions can visit e-commerce online marketing, online ordering and online transactions. Through simulation training, familiar with e-commerce operation process, participate in a virtual operating activity, which an increase of virtual direct experience.

\section{Strengthen network monitoring in the E-commerce accounting}

Network regulatory issues cannot be ignored, the application of modern technology to enhance controlmonitoring capabilities, strengthen the audit oversight 
functions essential. In the context of high-level computer network, high-level financial management, the use of mathematics, statistics, operations research, economics and other aspects of the theory, the use of computers can run high-level mathematical model of economic activity, indepth understanding and economic development and change control activities inherent laws seek benign economic management solutions that provide a scientific basis.

\section{CONCLUSIONS}

E-commerce network is developing rapidly. There is no absolute security of e-commerce, e-commerce is facing a new environment of financial accounting, in order to make our existing financial accounting system cannot lose their accounts in the new environment effect, and we must fully understand the financial and accounting information on ecommerce environment, to guarantee the absolute security of financial information in e-commerce environment.

\section{References}

[1] Chen Jiali. Commerce network based Financial Accounting Development [J] enterprise economy, 2012,06: 128-132.

[2] Zhang Jia. Based on analysis of development of e-commerce network of financial accounting [J] providers, 2013,16: 115.

[3] Chen Si. Studied accounting issues under the e-commerce environment [D]. Beijing University of Posts and Telecommunications, 2008.

[4] He Yuanzhen. Based on the development of e- financial accounting of enterprises [J] electronic production, 2014,13: 293.

[5] Wang Erjuan. Impact of e-commerce development of traditional accounting [D]. Anhui University of Finance and Economics, 2013.

[6] Tang Changyi. Developing a network of financial accounting problems and countermeasures $[\mathrm{J}]$ Liaoning Economic Vocational Technical Institute Liaoning Economic Management Cadre College, 2002,03: 9-10. 